\title{
The Role of Civil Society Council of Southern Thailand on Peace Talk under Junta Since 2014
}

\author{
Fareeda Panjor \\ Center for Conflict Studies and Cultural Diversity \\ Prince of Songkla University, Pattani Campus \\ Pattani, Thailand \\ Fareeda028@gmail.com
}

\begin{abstract}
The violent conflict in Thailand's Deep South, the region of Pattani, Yala, Narathiwat and four districts of Songkla provinces since 2004, has caused more than 6,000 deaths and injury of nearly 12,000 people. At the beginning of the conflict in 2004-2005, the civil society of Thailand's Deep South did not have the role in solving the problem seriously. However, in 20062012, Civil Society Council of Southern Thailand which in 2011 by 20 civil society organizations started to raise the core issue of the conflict as the power struggle between Melayu Muslim movements and Thai State. The political solution from civil society practically envisioned and advocated a political solution to the conflict parties by peace talk which officially began on 28 February 2013 and March 2015.
\end{abstract}

The question is due to unstable politics and distrust between conflict parties including dividing among CSOs supporting and suspicious to the peace talks, how Civil Society Council is dealing with these challenges. The study finds that concerning the present National Council for Peace and Order administration (Junta) since 2014, there is a confusing signal from the Thai Government to contribute commitment and sincerity to the peace talk and there is internal conflict among movement organizations while the violence is still going. Civil Society Council has found the window of opportunity and strategies for improvement including seeking more constructive collaboration under critique and tension between civilian and military government.

Keywords - Civil Society Council of Southernmost Thailand; National Council for Peace and Order; Thailand's Deep Sout; Peace Talk.

\section{INTRODUCTION}

The conflict in southern Thailand (Patani), the region of Pattani, Yala, Narathiwat and four districts of Songkla provinces is caused by the competing power struggle between Malay Muslim movement which became more distinct upon "political legitimacy" over the Thailand's Deep South. The violence from the clashing of the movement's militant wing and Thai security agencies had emerged in the late 2001 and escalated since January 2004. Since 2004, after a large group of insurgents raided Army depot in Narathiwas, more than 6,000 deaths and injury of nearly 12,000 from violence and counterviolence. This brings region controlled by Thai State and security agencies to the enforcement of special laws such as emergency decree and martial law. It led to several cases of human rights violation by the army since then.

\section{CIVIL SOCIETY IN CONFLICT TRANSFORMATION AND THEIR ROLE IN PEACE PROCESS}

Leading researcher such as Thania Paffenholz explains that the roles of CSOs in the peace process are varied. She explains that CSOs is a significant actor although, in reality, there is less chance for them on the negotiation table. Civil society involves many dimension of peace process beyond the context and relationship with the state. Thailand's Deep South is at the time of armed conflict which needs many civil society roles such as socialization, social cohesion, peace education and opening common space. The other functions that are also important too such as monitoring, advocacy (especially on human rights and peace) and facilitation on peace negotiation [1]. However, this time civil society could not decrease violence because they cannot change the behavior of conflict parties.

Moreover, the phrases of conflict are also the opportunity conflict transformation. Norbert Ropers argued that CSOs working in conflict transformation need strategies that can create conflict protection impact between ethnic groups. Moreover, creating strategies for dialogue can change the perception of conflict parties. The strategic work of CSOs could guarantee that it will support sustainable conflict transformation, democracy and social justice [2].

For the context of Thailand's Deep South even there are the formation civil society networks since 2007, but there is an argument from the study of Apichaya O-In that since 20042012 that peace constituencies of Thailand's Deep South had the problem on forging strategies and building trust. It is because there were no connectors among civil society organizations. It is obvious that civil society organizations are fragmented and depend on some leaders [3].That was the reason that brings civil society recognized that it is necessary to build the strength of civil society by forming the effective mechanism from different backgrounds so they can exchange ideas or problem.

\section{THE FORGING OF CIVIL SOCIETY OF THAILAND'S DEEP SOUTH}

After the outbreaking situations, the government has attempted to solve the conflict. However, they excluded the 
participation of people and civil society organizations. At the beginning of the conflict in 2004-2005, the three policies of Thaksin Shinawatra's government only focused on restructuring and integrating government bureaucracy in the region but did not accommodate the other sectors' idea such as civil society to solve the southern problem seriously. Even though civil society had more opening space to talk about their issues, but their role was less relevant. In 2005, there was a National Reconciliation Commission or NRC which is the independent commission that responded in resolving the problem by providing a public space to a dialogue and meeting among government officials, religious leaders and local leaders to find a solution in the region [4].

Even there were important recommendations from NRC, but some argued that NRC report did not mention about the core of conflict as competing of the power struggle between Malay Muslim movement and Thai State upon "political legitimacy" over the Deep South of Thailand. The claim of violence in the report was only a work of a small number of 'bad' people and finally, the role of NRC has faded since the military coup in 2006 [5]. After the coup, civilian state agency played the role rather than military while there was expanding violence and unstable politic situation, independent civil society actors, alternative and local media, academic institutions had been creating a remarkable public sphere for promoting a culture of peace and the way to transform the underlying conflict. They were all supported in many scopes of works mainly were rehabilitation, human rights, communication, local economics and development but they were fragmented and depending on financial support [6].

From 2006 to 2012, the power of civil society had been growing steadily, and they began to assemble as the prominent networks before 2012 such as the emergence of the Women Civil Society Network, the Muslim Attorney Centre and Civil Society Council of Southern Thailand. Moreover, academic communities both inside and outside the region had the opportunity to raise the core issue of the conflict as the power struggle between Malay Muslim movement and Thai State [6].

\section{IV.THE ROLE OF CIVIL SOCIETY COUNCIL OF SOUTHERN THAILAND ON THE EMERGING OF PEACE TALK}

Under the emerging Prime Minister Yingluck Shinawatra's administration (2011-2014), by 2013 on 28 February at Kuala Lumpur, Malaysia, there was a signing of a General Consensus on Peace Dialogue Process between the Government of Thailand and Barisan Revolusi Nasional (BRN), the secretive and most influential organization movement. Even there was a good sign for peace, but society both in and outside region criticized the government peace talk policy to the illegal insurgent group and questioned to the representativeness of Ustaz Hassan Taib. On 25 October 2014, a new group emerged called the Majlis Syura Patani (Patani Consultative Council) or MARA Patani. Envisioned as an umbrella organization uniting the disparate Malay-Patani groups. They aimed to seek a political solution to the conflict through peace talks with the Thai government which began in March 2015.

Regarding peace process, since 2005 - 2012, there were many informal peace talks, but most civil society organizations did not know about unsuccessful peace talk situation in the past and did not recognize their role to rebuild and to create a mutual trust to the conflict parties. However, after 2013, there was first presence of formal peace dialogue process, CSOs could consolidate their networks to support peace talks through advocating the government policy. However, it is interesting that there is an intensive debate between different societal groups with opposing standpoints of peace dialogue because of their oriented to different political ideologies. As a result, many civil society organizations still distrusted to each other, and among them, there are pro and cons on peace negotiation. The divided CSOs situation also contribute less tolerance and distrust among conflict parties. $\square$

The Civil Society Council of Southernmost Thailand established in 2011, and it is the first distinguish umbrella organizations which include 23 different civil society organizations in Thailand's Deep South. Its function is to be the common platform for civil society organizations and to drive public policy recommendations. Since 2011-2015, there were four strategies which Civil Society Council promoted 1) expanding democracy and maintaining justice 2) supporting ceasing direct violence 3) supporting people's livelihood, identity and culture 4) developing the strength of civil society council mechanism. However, amidst the political solution supporting on political legitimacy, there was just expanding democracy and maintaining justice strategies that attracted public and government attention. The decentralization over Thailand's Deep South raised by Civil Society Council and academics as the political solution rather than militarization [6].

In 2012, there was the developing of many decentralized models proposed from academics, CEOs and politicians. Later the same year, the decentralization essence was formally indicated in the policy of administration and development on southern Thailand 2012-2014. However, after the Junta of National Council for Peace and Order or NCPO. The supporting of decentralization as the political resolution to core political legitimacy problem resolution had been fading with the confusing signals from the Government of Thailand to contribute commitment and sincerity to the peace talks. On the other hands, it is the fact that there is internal conflict among movement organization, without the explicit endorsement of the BRN, recognized as the most influential movement with the largest number of fighters, MARA's status as the representative of the movement organizations remains unclear. With the violence that still going on and suspicious political circumstance is challenging to Civil Society Council and other CSOs. $\square$

Civil Society Council has been taking proactive role recently in the peace process because it considered that 
working as the network which includes members both inside and outside the area. Moreover, it could be a place where many organizations can exchange idea, knowledge with the strong declaration to conflict parties to stop the violence and ceasefire since 2011.However, it still has low levels of participation in the peace talks due to unstable politics and distrust between conflict parties including dividing among CSOs both supporting and suspicious to the peace talk process [6].

Besides, there are also weaknesses of Civil Society Council members, some groups were supported by governments or other interest groups, but there is a big problem as long as they are supported by the public. However, if there is any intervention by the interest groups, there would be concerns to forge the peace constituencies. Other weaknesses are 1) less inclusive members of human rights and young people 2) less communication to the public both inside and outside conflict region 3) They are working under the Junta political circumstance which might effect from the legal measure [6].

However, the Prime Minister's Order 230 and National Security Council's policy still maintaining and opening peace talk and engagement of civil society to the political solution which is not functional in the other Thailand regions. The initiative of promoting peace zone and policy recommendation for conflict parties from Woman Agenda for Peace (PAW) is a good example of Civil Society Council members to promote safe space for all civilians who targeted by the chronic violence. However, the progress is still low [6].

To summarize, the study found that there are positive changes under the political opportunities to support of Civil Society Council to involve more on the peace process in southern Thailand such as socialization, social cohesion and policy advocacy. However, there are still many concerns about relationship between Civil Society Council, many different CSOs and military government. This study raised the concerns on the involvement between Civil Society Council which promotes peace and reconciliation and different opinions from other civil society organizations which they are still suspicious of military government. Another question raised is how far
Civil Society Council could engage with the government without being assimilated as a part of government mechanism but maintaining the sphere of multi-partiality in the political sphere.

\section{References}

[1] Paffenholz, T. (2010). Civil Society and Peace Building: A Critical

Assessment. Boulder, CO: Lynne Rienner.

[2] Ropers, 2002. Civil societies peace Constituencies: NGO Involvement in conflict resolution-Areas of activities and lessons learned. In Promoting Peace: the role of civilian conflict resolution. Steamfli Publishers Ltd. Berne.

[3] O-In, A. (2012). Partnership of International Funding Agencies and Civil Society Organizations in Peace Building Process in Southern Border Provinces of Thailand (Degree of Master of Arts Program in International Development Studies). Chulalongkorn University,Bangkok.

[4] Jitpiromsri, S. (2008, March 30). Phoenix Under the Sun Light: Civil Society Movement in Southern Thai Provinces. Retrieved from http://www.deepsouthwatch.org/node/229

[5] McCargo, D. (2010). Thailand's National Reconciliation Commission: a flawed response to the Southern Conflict. Journal of Global Change, Peace \& Security, 22 (1), 83-84.

[6] Civil Society Council of Southern Thailand. (2016) .Report of 12 Years Civil Society in Southern Thailand and the New Roadmap of Civil Society Council of Southern Thailand in 2016-2018. Bangkok: Local Development Institute. 